\title{
Molecular and serological prevalence of Toxoplasma gondii and Anaplasma spp. infection in goats from Chongqing Municipality, China
}

Zuoyong Zhou ${ }^{1,2, a,{ }^{*}}$, Yutong $\mathrm{Wu}^{3, \mathrm{a}}$, Yiwang $\mathrm{Chen}^{1,2, \mathrm{a}}$, Zhiying Wang ${ }^{1,2}$, Shijun $\mathrm{Hu}^{1,2}$, Rongqiong Zhou ${ }^{1,2}$, Chunxia Dong ${ }^{4}$, Hongquan $\operatorname{Lin}^{4}$, and Kui Nie ${ }^{5}$

${ }^{1}$ College of Animal Science, Rongchang Campus of Southwest University, No. 160 Xueyuan Road, Rongchang District, Chongqing 402460, PR China

${ }^{2}$ Veterinary Science Engineering Research Center of Chongqing, No. 160 Xueyuan Road, Rongchang District, Chongqing 402460, PR China

${ }^{3}$ Guizhou Institute of Animal Husbandry and Veterinary Medicine, No. 2 Laolipo, Naming District, Guizhou 550005, PR China

${ }^{4}$ Chongqing Animal Disease Prevention and Control Center, Chongqing 400174, PR China

${ }^{5}$ College of Animal Science and Technology, Southwest University, Beibei District Chongqing 400715, PR China

Received 20 December 2017, Accepted 26 March 2018, Published online 10 April 2018

\begin{abstract}
Toxoplasmosis and anaplasmosis are severe zoonotic diseases, the former caused by Toxoplasma gondii and the latter by Anaplasma spp. In the present study, 332 goat blood samples were randomly collected from Chongqing Municipality, China to screen for T. gondii and Anaplasma spp. We used a polymerase chain reaction (PCR) to detect DNA, and enzyme-linked immunosorbent assay (ELISA) to test for T. gondii antibodies. The prevalence of T. gondii and Anaplasma spp. was $38 \%$ and $35 \%$ respectively by PCR, and $42 \%$ for T. gondii antibodies by ELISA. The co-infection rate by T. gondii and Anaplasma was $13 \%$, where the two predominant pathogens co-infecting were Anaplasma phagocytophilum + A. bovis (10\%), followed by T. gondii + A. phagocytophilum (9.64\%). While co-infection by three pathogens varied ranging from $1.81 \%$ to $5.72 \%$, less than $1 \%$ of goats were found to be positive for four pathogens. This is the first investigation of T. gondii and Anaplasma spp. infection in goats from Chongqing.
\end{abstract}

Keywords: Toxoplasma gondii, Anaplasma spp, Goat, Prevalence, Chongqing

Résumé-Prévalence moléculaire et sérologique des infections à Toxoplasma gondii et Anaplasma spp. chez les chèvres de la municipalité de Chongqing, Chine. La toxoplasmose et l'anaplasmose sont des zoonoses sévères, la première causée par Toxoplasma gondii et la seconde par Anaplasma spp. Dans la présente étude, 332 échantillons de sang de chèvres ont été prélevés au hasard dans la municipalité de Chongqing en Chine pour détecter T. gondii et Anaplasma spp. L'ADN a été détecté par PCR, et les anticorps dirigés contre T. gondii par ELISA. La prévalence de T. gondii et Anaplasma spp. étaient respectivement de $38 \%$ et $35 \%$ par PCR, et de $42 \%$ pour les anticorps anti- T. gondii par ELISA. Le taux de co-infection par T. gondii et Anaplasma était de $13 \%$, où la co-infection prédominante à deux pathogènes était Anaplasma phagocytophilum + A. bovis (10\%) suivie de T. gondii + A. phagocytophilum (9,64\%). Alors que la co-infection par trois agents pathogènes variait de $1,81 \%$ à $5,72 \%$, moins de $1 \%$ des chèvres ont été trouvés positives pour quatre pathogènes. Ceci est la première enquête sur les infections à $T$. gondii et Anaplasma spp. chez les chèvres de Chongqing.

\section{Introduction}

Protozoan parasites and tick-borne infectious pathogens are common threats to both humans and animals

\footnotetext{
*Corresponding author: zzyxnny@163.com

a These authors contributed equally to the work.
}

$[8,30]$. The causative agent of toxoplasmosis, Toxoplasma gondii, is an obligate apicomplexan intracellular protozoan that can cause behavioral changes, neuropsychiatric disorders, abortions, stillbirth or fetal malformations, infertility and even death in humans and other mammals $[19,21,24,26]$. Anaplasmosis is caused by Anaplasma, a tick-borne pathogen that leads to inappetence, progressive 


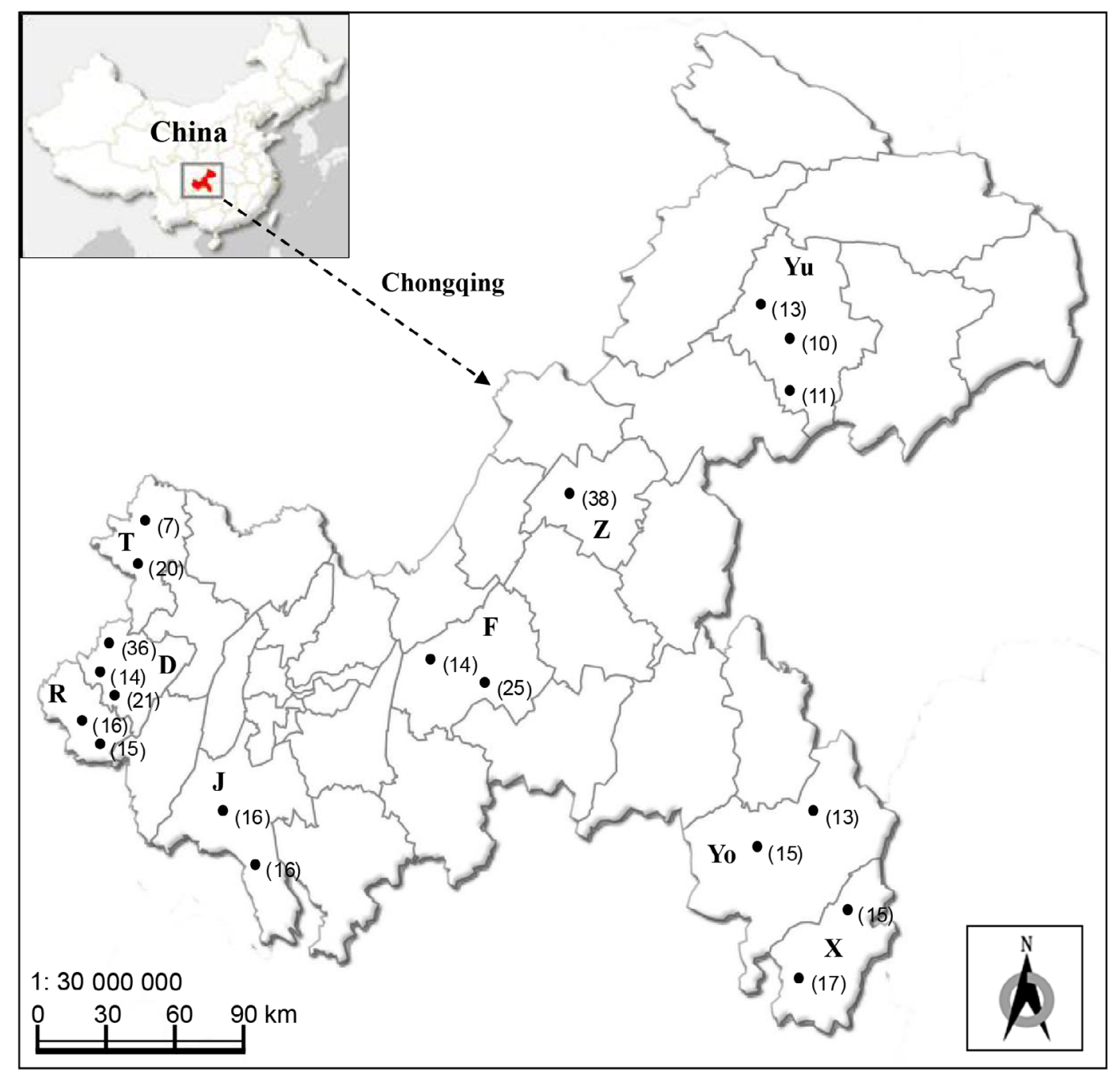

Figure 1. Map of surveyed counties located in Chongqing Municipality, China, where the blood samples of goats were collected. T: Tongnan; D: Dazu; R: Rongchang; J: Jiangjin; F: Fuling; Z: Zhongxian; Yu: Yunyang; Yo: Youyang; X: Xiushan. The black dots indicate the farms. The number of samples collected from the corresponding goat farm is indicated in parentheses.

anemia, fever, weight loss, milk production decrease, abortion, and sometimes death $[14,18,25,34]$. Infection by T. gondii and Anaplasma in goats not only affects the economic development of the animal industry, but can also have serious effects on human health $[6,7,23]$. Several surveys of $T$. gondii infection $[20,31,32,33,40,41]$ or Anaplasma infection [18,36-38] in goats have been reported in some regions of China. However, they all focus only on T. gondii or Anaplasma infection; none examine co-infection by these pathogens. The presence of A. phagocytophilum can alter the immune system of the host and make the animal more susceptible to other parasitic agents [22]. It is important to study the relevance of this phenomenon regarding T. gondii and Anaplasma spp. infection in goats in Chongqing.

Chongqing Municipality is located in southwest China and has been incorporated into the national "Advantage of agricultural products regional planning". It is recognized as a key area for goat breeding in China. However, there are no data on the prevalence of T. gondii and Anaplasma spp. infections in goats in Chongqing. The objective of this study was to investigate the prevalence of $T$. gondii, Anaplasma spp. and co-infection in goats in Chongqing, through detection of relevant pathogen DNA by PCR, and detection of $T$. gondii antibodies by enzyme-linked immunosorbent assay (ELISA).

\section{Materials and methods \\ Collection of blood samples and DNA extraction}

The blood samples were collected from 332 apparently healthy goats randomly selected from 19 farms in 9 counties (Jiangjin, Dazu, Fuling, Rongchang, Tongnan, Youyang, Xiushan, Yunyang, and Zhongxian) of Chongqing (Fig. 1), from October 2014 to April 2016. The breeds of goats included the Boer goat, Dazu black goat, Chengdu ma goat, Nanjiang yellow goat, and Hybrid black goat. The sera were stored at $-20^{\circ} \mathrm{C}$ for T. gondii antibodies detection, and the blood samples were used for genomic 
Table 1. Primers for T. gondii and Anaplasma detection in goats and PCR amplification conditions.

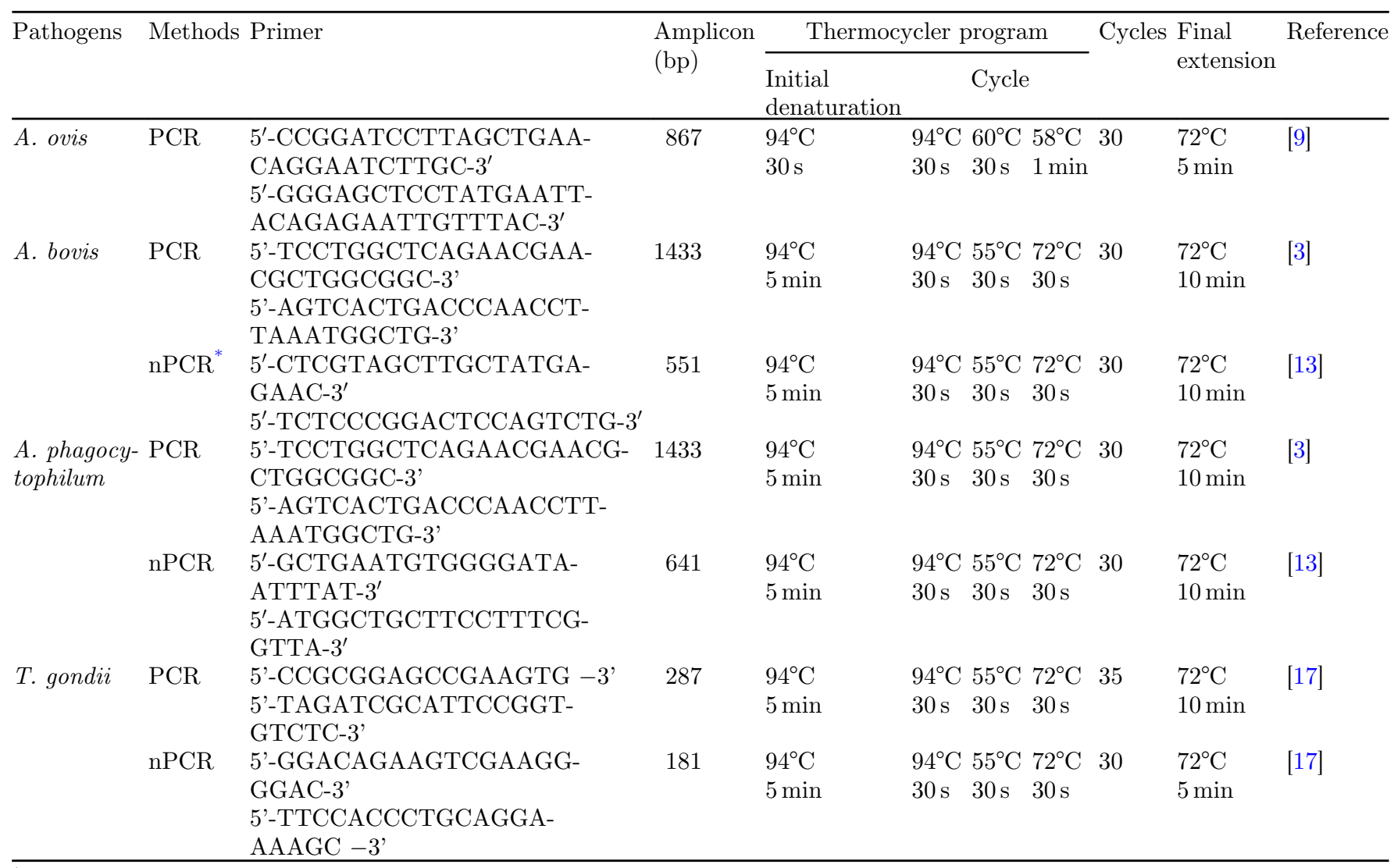

Nested PCR.

DNA extraction using a Wizard $^{\circledR}$ Genomic DNA Purification Kit (Promega, Madison, WI, USA), according to the manufacturer's instructions.

\section{Detection of $T$. gondii and Anaplasma DNA by PCR}

Infections by T. gondii and Anaplasma spp. (A. ovis, A. bovis, and A. phagocytophilum) were detected by PCR in a reaction volume of $25 \mu \mathrm{L}$ containing the following reagents: $12.5 \mu \mathrm{L}$ of the PCR mix $(2 \times)$ (Takara Dalian, China), $1 \mu \mathrm{L}$ of each forward and reverse primer

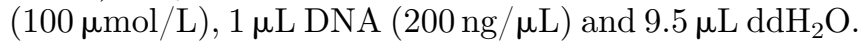
The amplified PCR products were separated by electrophoresis in $1.5 \%$ agarose gels. The primers and amplification conditions are listed in Table 1.

\section{Detection of $T$. gondii antibodies by ELISA}

Serum antibodies against T. gondii were screened using the IDEXX Toxotest ELISA kit (IDEXX Laboratory, Westbrook, ME, USA), according to the manufacturer's recommendations. The serum samples and controls were diluted to 1:400 and tested in duplicate. The optical density (OD) was measured at $450 \mathrm{~nm}$ with an ELISA plate reader (Thermo Fisher, Waltham, MA, USA). The $\mathrm{S} / \mathrm{P}$ (samples/positive control) percent for each sample was calculated according to the formula: $\mathrm{S} / \mathrm{P} \%=\left(\mathrm{OD}_{450}\right.$ of the sample $-\mathrm{OD}_{450}$ of negative control $) /\left(\mathrm{OD}_{450}\right.$ of positive control $-\mathrm{OD}_{450}$ of negative control) $\times 100 . \mathrm{S} / \mathrm{P} \%$ of samples less than 20 were considered negative for T. gondii antibodies. Samples with $\mathrm{S} / \mathrm{P} \%$ between 20 and 30 were considered questionable. If the $\mathrm{S} / \mathrm{P}$ percentage was higher than or equal to 30, the samples were considered positive. If a sample remained suspect after a second run, a new sample from the same animal was collected and analyzed again. If the test result was again suspect, this sample was considered positive for T. gondii antibodies.

\section{Statistical analysis}

The prevalence of T. gondii and Anaplasma infection in goats of different sexes and ages was analyzed using the Chi Square Test in SPSS (version 18.0, SPSS Inc., Chicago, IL, USA), and the probability $(p)$ value of $<0.05$ was considered statistically significant.

\section{Results and discussion}

The molecular prevalence of T. gondii was estimated to be $37.65 \%$ population, and the seroprevalence was $42.47 \%$ by ELISA (Table 2). The prevalence of T. gondii in goats has been reported to vary from $1.34 \%$ to $55.18 \%$ $[1,2,4,11,12,29]$. The relatively high prevalence of T. gondii in goats in Chongqing may be related to: 1) the oocysts of $T$. gondii excreted by infected cats that can easily develop to infective stages under the subtropical 
Table 2. Overall prevalence of T. gondii and Anaplasma infection in goats in Chongqing, southwest China tested by PCR and ELISA.

\begin{tabular}{|c|c|c|c|c|c|c|}
\hline \multirow[t]{2}{*}{ Variables } & \multicolumn{4}{|c|}{ Prevalence of $T$. gondii infection (\%) } & \multicolumn{2}{|c|}{ Prevalence of Anaplasma infection (\%) } \\
\hline & $\begin{array}{l}\text { Prevalence by } \\
\text { PCR (positive/ } \\
\text { examined) }\end{array}$ & $95 \% \mathrm{CI}^{*}$ & $\begin{array}{l}\text { Prevalence by } \\
\text { ELISA (positive/ } \\
\text { examined) }\end{array}$ & $95 \% \mathrm{CI}$ & $\begin{array}{l}\text { Prevalence by } \\
\text { PCR (positive/ } \\
\text { examined) }\end{array}$ & $95 \% \mathrm{CI}$ \\
\hline \multicolumn{7}{|l|}{ Location } \\
\hline Jiangjin & $34.38(11 / 32)$ & $18.57-53.19$ & $31.25(10 / 32)$ & $16.12-50.01$ & $0(0 / 32)$ & $0.00-10.89$ \\
\hline Dazu & $50.70(36 / 71)$ & $38.56-62.78$ & $60.56(43 / 71)$ & $48.25-71.97$ & $14.08(10 / 71)$ & $6.97-24.38$ \\
\hline Fuling & $33.33(13 / 39)$ & $19.09-50.22$ & $41.03(16 / 39)$ & $25.57-57.90$ & $20.51(8 / 39)$ & $9.30-36.46$ \\
\hline Rongchang & $45.16(14 / 31)$ & $27.32-63.97$ & $35.48(11 / 31)$ & $19.23-54.63$ & $38.71(12 / 31)$ & $21.85-57.81$ \\
\hline Tongnan & $29.63(8 / 27)$ & $13.75-50.18$ & $44.44(12 / 27)$ & $25.48-64.67$ & $77.78(21 / 27)$ & $57.74-91.38$ \\
\hline Youyang & $35.71(10 / 28)$ & $18.64-55.93$ & $39.29(11 / 28)$ & $21.50-59.42$ & $78.57(22 / 28)$ & $59.05-91.70$ \\
\hline Xiushan & $37.50(12 / 32)$ & $21.10-56.31$ & $53.13(17 / 32)$ & $34.74-70.91$ & $56.25(18 / 32)$ & $37.66-73.64$ \\
\hline Yunyang & $41.18(14 / 34)$ & $24.65-59.30$ & $41.18(14 / 34)$ & $24.65-59.30$ & $41.18(14 / 34)$ & $24.65-59.30$ \\
\hline Zhongxian & $18.42(7 / 38)$ & 7.74-34.33 & $18.42(7 / 38)$ & 7.74-34.33 & $28.95(11 / 38)$ & $15.42-45.90$ \\
\hline \multicolumn{7}{|l|}{ Gender } \\
\hline Male & $31.91(30 / 94)$ & $22.67-42.33$ & $36.17(34 / 94)$ & $26.51-46.73$ & $37.23(35 / 94)$ & $27.48-47.82$ \\
\hline Female & $39.92(95 / 238)$ & $33.64-46.44$ & $44.96(107 / 238)$ & $38.53-51.52$ & $34.03(81 / 238)$ & $28.04-40.43$ \\
\hline \multicolumn{7}{|l|}{ Age } \\
\hline$<1$ year & $37.07(43 / 116)$ & $28.29-46.53$ & $38.79(45 / 116)$ & $29.89-48.28$ & $29.31(34 / 116)$ & $21.23-38.48$ \\
\hline$\geq 1$ year & $37.96(82 / 216)$ & $31.47-44.80$ & $44.44(96 / 216)$ & $37.70-51.34$ & $37.96(82 / 216)$ & $31.47-44.80$ \\
\hline Total & $37.65(125 / 332)$ & $32.42-43.10$ & $42.47(141 / 332)$ & $37.09-47.98$ & $34.94(116 / 332)$ & $29.82-40.34$ \\
\hline
\end{tabular}

* $95 \%$ confidence intervals.

monsoon climate and humid weather in Chongqing and that are ingested by goats during grazing, and 2) the fact that most goats investigated in Chongqing were semihoused, potentially increasing the risk of $T$. gondii sporulated oocyst ingestion in wild grazing conditions. The prevalence of $T$. gondii in goats in Chongqing Municipality was obviously higher than that of goats in other places in China, with the prevalence varying from $3.8 \%$ to $14.1 \%[16,20,31,32,40]$. Similar to a previous report [31], the prevalence of T. gondii in female goats ( $39.91 \%$ by PCR and $44.96 \%$ by ELISA) in Chongqing was higher than that of males $(31.91 \%$ by PCR and $36.17 \%$ by ELISA), and goats aged 1 year or more were more highly infected than those less than one year old. The overall prevalence of Anaplasma infection in goats in Chongqing was $34.94 \%$ (Table 2), which was comparable to Anaplasma infection in Yunnan and Henan provinces (36.5\%) [39], but higher than rates reported by other investigators for goats $[36,37]$ and lower than rates for goats from Henan, Guizhou, Zhejiang and Hubei provinces in China [18]. Contrary to the prevalence of T. gondii in goats by sex, the prevalence of Anaplasma (37.23\%) was higher in males than in females (34.03\%). The prevalence of Anaplasma in goats aged one year or more $(37.96 \%)$ was higher than that in goats less than 1 year old $(29.31 \%)$. This is consistent with other reports $[5,15]$. The difference could be due to the fact that older animals are exposed to several tick seasons [5] and have a greater chance of exposure to ticks carrying Anaplasma spp. [15]. Similar to a previous study [37], $22.89 \%(76 / 332)$ of goats were positive for $A$. phagocytophilum infection followed by A. bovis $(62 / 332$,
$18.67 \%$ ) and $A$. ovis $(43 / 332,12.95 \%)$, which was not consistent with other reports indicating that the prevalence of $A$. phagocytophilum in goats was lower than that of $A$. bovis and A. ovis [18]. In addition, the prevalence of A. phagocytophilum in goats in this study was higher than that of goats in Slovakia [8]. Unlike a previous report [18], the dominant co-infection of $A$. phagocytophilum $+A$. bovis $(34 / 332,10.24 \%)$ was higher than $A$. phagocytophilum + A. ovis $(22 / 332,6.63 \%)$ and A. bovis + A. ovis (16/ $332,4.82 \%)$. Co-infection by three Anaplasma spp. occurred in only $2.11 \%$ of the goats studied, which is similar to the other report [18] (Fig. 2).

Co-infection by T. gondii and Anaplasma has been reported in rodents [27], dogs [10], ticks [35], and wild boars [22]. However, a survey on the occurrence of goats co-infected by T. gondii and Anaplasma was only reported in Slovakia [8]. In this study, 43 out of 332 (12.95\%) goats were positive for T. gondii and Anaplasma (Fig. 2), indicating a relatively high prevalence of these two pathogens. The dominant co-infection between T. gondii and a single Anaplasma species was T. gondii $+A$. phagocytophilum $(9.64 \%, 32 / 332)$, followed by T. gondii + A. bovis $(8.43 \%, 28 / 332)$ and T. gondii $+A$. ovis $(4.22 \%, 14 / 332)$. The high prevalence of $A$. phagocytophilum and $T$. gondii co-infection confirms the hypothesis that the presence of A. phagocytophilum can alter the immune system of the host and make the animal more susceptible to other parasitic agents [22]. A. bovis was first reported to infect goats in China by Liu et al. (2012). The high prevalence of A bovis in this study also confirmed that goats may be an important natural 


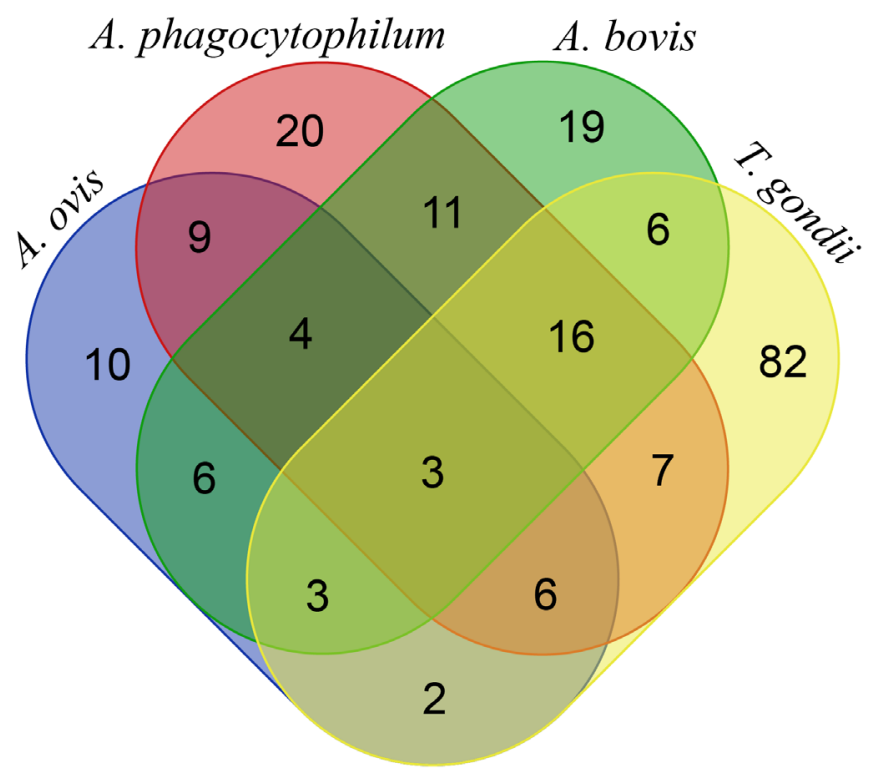

Figure 2. Venn diagram of mixed infection by T. gondii and Anaplasma in goats in Chongqing, southwest China. The number of goats tested positive for T. gondii and Anaplasma (A. ovis, A. bovis and A. phagocytophilum) infection is indicated by different colors in oval circles; the number of goats co-infected by pathogens is shown in the cross-over areas $(\mathrm{n}=332)$.

reservoir for this organism [18]. Three-pathogen coinfection by $A$. ovis $+A$. phagocytophilum $+T$. gondii, A. phagocytophilum + A. bovis + T. gondii, and A. bovis + A. ovis + T. gondii was $2.71 \%(9 / 332), 5.72 \%(19 / 332)$ and $1.81 \%(6 / 332)$ respectively. Four-pathogen co-infection (A. ovis, A. bovis, A. phagocytophilum and T. gondii) was simultaneously detected in 3 goats $(0.9 \%)$ (Fig. 2$)$. The main species of tick in Chongqing is Boophilus microplus [28], which is one of the vectors of Anaplasma phagocytophilum in China [37]. Since T. gondii has already been detected in ticks [35], a study of T. gondii and Anaplasma carriage by Boophilus microplus in Chongqing should be carried out.

Acknowledgments. This work was funded by the Social Undertakings and Livelihood Security Technology Innovation Projects of Chongqing (CSTC2015SHMSZX80020). We greatly appreciate help from Prof. Ian Robertson from Murdoch University who provided the Excel spreadsheet for the 95\% CI calculation, and Dr. Narayan C. Rath from the United States Department of Agriculture for English language editing of this manuscript.

\section{Conflict of interest}

None of the authors have any conflict of interest.

\section{References}

1. Ahmed H, Malik A, Arshad M, Mustafa I, Khan MR, Afzal MS, Ali S, Mobeen M, Simsek S. 2016. Seroprevalence and spatial distribution of toxoplasmosis in sheep and goats in
North-Eastern Region of Pakistan. Korean Journal of Parasitology, 54, 439-446.

2. Amdouni Y, Rjeibi MR, Rouatbi M, Amairia S, Awadi S, Gharbi M. 2017. Molecular detection of Toxoplasma gondii infection in slaughtered ruminants (sheep, goats and cattle) in Northwest Tunisia. Meat Science, 133, 180-184.

3. Barlough JE, Madigan JE, DeRock E, Bigornia L. 1996. Nested polymerase chain reaction for detection of Ehrlichia equi genomic DNA in horses and ticks (Ixodes pacificus). Veterinary Parasitology, 63, 319-329.

4. Bawm S, Maung WY, Win MY, Thu MJ, Chel HM, Khaing TA, Wai SS, Htun LL, Myaing TT, Tiwananthagorn S, Igarashi M, Katakura K. 2016. Serological survey and factors associated with Toxoplasma gondii infection in domestic goats in Myanmar. Scientifica, 2016, 4794318.

5. Belkahia H, Said MB, Hamdi SE, Yahiaoui M, Gharbi M, Daaloul-Jedidi M, Mhadhbi M, Jedidi M, Darghouth MA, Klabi I. 2014. First molecular identification and genetic characterization of Anaplasma ovis in sheep from Tunisia. Small Ruminant Research, 121, 404-410.

6. Chen SM, Dumler JS, Bakken JS, Walker DH. 1994. Identification of a granulocytotropic Ehrlichia species as the etiologic agent of human disease. Journal of Clinical Microbiology, 32, 589-595

7. Chochlakis D, Ioannou I, Tselentis Y, Psaroulaki A. 2010 Human anaplasmosis and Anaplasma ovis variant. Emerging Infectious Diseases, 16, 1031-1032.

8. Cobadiova A, Reiterova K, Derdakova M, Spilovska S, Turcekova L, Hviscova I, Hisira V. 2013. Toxoplasma gondii, Neospora caninum and tick-transmitted bacterium Anaplasma phagocytophilum infections in one selected goat farm in Slovakia. Acta Parasitologica, 58, 541-546.

9. de la Fuente J, Atkinson MW, Naranjo V, Fernandez DMI, Mangold AJ, Keating KA, Kocan KM. 2007. Sequence analysis of the msp4 gene of Anaplasma ovis strains. Veterinary Microbiology, 119, 375-381.

10. Hamel D, Shukullari E, Rapti D, Silaghi C, Pfister K, Rehbein S. 2016. Parasites and vector-borne pathogens in client-owned dogs in Albania. Blood pathogens and seroprevalences of parasitic and other infectious agents. Parasitology Research 115, 489-499.

11. Iovu A, Gyorke A, Mircean V, Gavrea R, Cozma V. 2012. Seroprevalence of Toxoplasma gondii and Neospora caninum in dairy goats from Romania. Veterinary Parasitology, $186,470-474$

12. Kalambhe D, Gill J, Singh BB. 2017. Molecular detection of Toxoplasma gondii in the slaughter sheep and goats from North India. Veterinary Parasitology, 241, 35-38.

13. Kawahara M, Rikihisa Y, Lin Q, Isogai E, Tahara K, Itagaki A, Hiramitsu Y, Tajima T. 2006. Novel genetic variants of Anaplasma phagocytophilum, Anaplasma bovis, Anaplasma centrale, and a novel Ehrlichia sp. in wild deer and ticks on two major islands in Japan. Applied \& Environmental Microbiology, 72, 1102-1109.

14. Kocan KM, Blouin EF, Barbet AF. 2000. Anaplasmosis control. Past, present, and future. Annals of the New York Academy of Sciences, 916, 501-509.

15. Lee SH, Jung BY, Kwak D. 2015. Evidence of Anaplasma spp. exposure in native Korean goats (Capra hircus coreanae). Veterinární Medicína, 60, 248-252.

16. Li F, Wang SP, Wang CJ, He SC, Wu X, Liu GH. 2016. Seroprevalence of Toxoplasma gondii in goats in Hunan province, China. Parasite, 23, 44.

17. Liu X. 2014. Comparative analysis of results on Toxoplasma infection by serosurvey and nested PCR in a goat farm. Northwest A \& F University, Yangling, Shaanxi, China. p. 19-20. (In Chinese). 
18. Liu Z, Ma M, Wang Z, Wang J, Peng Y, Li Y, Guan G, Luo J, Yin H. 2012. Molecular survey and genetic identification of Anaplasma species in goats from central and southern China. Applied \& Environmental Microbiology, 78, 464-470.

19. Menzies PI. 2011. Control of important causes of infectious abortion in sheep and goats. Veterinary Clinics of North America Food Animal Practice, 27, 81-93.

20. Miao Q, Huang SY, Qin SY, Yu X, Yang Y, Yang JF, Zhu XQ, Zou FC. 2015. Genetic characterization of Toxoplasma gondii in Yunnan black goats (Capra hircus) in southwest China by PCR-RFLP. Parasites \& Vectors, 8, 57.

21. Montoya JG, Liesenfeld O. 2004. Toxoplasmosis. Lancet, 363, 1965-1976.

22. Reiterova K, Spilovska S, Blanarova L, Derdakova M, Cobadiova A, Hisira V. 2016. Wild boar (Sus scrofa) reservoir host of Toxoplasma gondii, Neospora caninum and Anaplasma phagocytophilum in Slovakia. Acta Parasitologica, 61, 255-260.

23. Schluter D, Daubener W, Schares G, Gross U, Pleyer U, Luder C. 2014. Animals are key to human toxoplasmosis. International Journal of Medical Microbiology, 304, 917929.

24. Shiadeh MN, Rostami A, Pearce BD, Gholipourmalekabadi M, Newport DJ, Danesh M, Mehravar S, Seyyedtabaei SJ. 2016. The correlation between Toxoplasma gondii infection and prenatal depression in pregnant women. European Journal of Clinical Microbiology \& Infectious Diseases, 35, $1-7$.

25. Stuen S, Granquist EG, Silaghi C. 2013, Anaplasma phagocytophilum - a widespread multi-host pathogen with highly adaptive strategies. Frontiers in Cellular \& Infection Microbiology, 3, 31.

26. Sutterland AL, Fond G, Kuin A, Koeter MW, Lutter R, Van GT, Yolken R, Szoke A, Leboyer M, De HL. 2015. Beyond the association. Toxoplasma gondii in schizophrenia, bipolar disorder, and addiction: systematic review and metaanalysis. Acta Psychiatrica Scandinavica, 132, 161.

27. Tadin A, Tokarz R, Markotic A, Margaletic J, Turk N, Habus J, Svoboda P, Vucelja M, Desai A, Jain K, Lipkin, WI. 2016. Molecular survey of zoonotic agents in rodents and other small mammals in Croatia. American Journal of Tropical Medicine \& Hygiene, 94, 466-473.

28. Tang M, Nie K, Wu Q, Jin A, Wen C, Sun T, Li M, Xu H, Yao J, Huang W. 2003. Investigation of livestock and poultry parasites in Chongqing. Chinese Journal of Veterinary Parasitology, 11(1): 25-30. (In Chinese).

29. Tegegne D, Kelifa A, Abdurahaman M, Yohannes M. 2016. Seroepidemiology and associated risk factors of Toxoplasma gondii in sheep and goats in Southwestern Ethiopia. BMC Veterinary Research, 12, 280.

30. Torina A, Vicente J, Alongi A, Scimeca S, Turla R, Nicosia S, Di Marco V, Caracappa S, de la Fuente J. 2007. Observed prevalence of tick-borne pathogens in domestic animals in
Sicily, Italy during 2003-2005. Zoonoses Public Health, 54, $8-15$.

31. Wang CR, Qiu JH, Gao JF, Liu LM, Wang C, Liu Q, Yan C, Zhu XQ. 2011. Seroprevalence of Toxoplasma gondii infection in sheep and goats in northeastern China. Small Ruminant Research, 97, 130-133.

32. Xu P, Li X, Guo L, Li B, Wang J, Yu D, Zhao Q, Liu XG. 2014. Seroprevalence of Toxoplasma gondii infection in Liaoning Cashmere goat from northeastern China. Parasite, $21,22$.

33. Xu P, Li X, Tang F, Liu YH, Kou X, Zhao ML, Li B, Guo L, Liu XG, Zhao Q. 2015. Seroprevalence and risk factors for Toxoplasma gondii in sheep and goats in Jinzhou, Northeastern China. Tropical Biomedicine, 32, 563-567.

34. Yasini SP, Khaki Z, Rahbari S, Kazemi B, Amoli JS, Gharabaghi A, Jalali SM. 2012. Hematologic and Clinical Aspects of Experimental Ovine Anaplasmosis Caused by Anaplasma ovis in Iran. Iranian Journal of Parasitology, 7, 91-98.

35. Zajac V, Wojcik-Fatla A, Sawczyn A, Cisak E, Sroka J, Kloc A, Zajac Z, Buczek A, Dutkiewicz J, Bartosik K. 2017. Prevalence of infections and co-infections with 6 pathogens in Dermacentor reticulatus ticks collected in eastern Poland. Annals of Agricultural \& Environmental Medicine, 24, 26-32.

36. Zhang GL, Sun X, Zhao Y, Liu XM, Zheng Z, Sun Y, Liu R. 2013. Prevalence of Anaplasma spp. infection in a desert landscape region of Heshuo, Xinjiang. Zhonghua Liu Xing Bing Xue Za Zhi, 34, 147-151. (In Chinese).

37. Zhang L, Liu H, Xu B, Lu Q, Li L, Chang L, Zhang X, Fan D, Li G, Jin Y, Gui F, Shi Y, Li W, Xu J, Yu XJ. 2012. Anaplasma phagocytophilum infection in domestic animals in ten provinces/cities of China. American Journal of Tropical Medicine \& Hygiene, 87, 185-189.

38. Zhang Y, Lv Y, Cui Y, Wang J, Cao S, Jian F, Wang R, Zhang L, Ning C. 2016. First molecular evidence for the presence of Anaplasma DNA in milk from sheep and goats in China. Parasitology Research, 115, 2789-2795.

39. Zhang Y, Lv Y, Zhang F, Zhang W, Wang J, Cui Y, Wang R, Jian F, Zhang L, Ning C. 2016. Molecular and phylogenetic analysis of Anaplasma spp. in sheep and goats from six provinces of China. Journal of Veterinary Science, 17 (4), 523-529.

40. Zhao GH, Zhang MT, Lei LH, Shang CC, Cao DY, Tian TT, Li J, Xu JY, Yao YL, Chen DK, Zhu XQ. 2011. Seroprevalence of Toxoplasma gondii infection in dairy goats in Shaanxi Province, Northwestern China. Parasites \& Vectors, 4, 47

41. Zou F, Yu X, Yang Y, Hu S, Chang H, Yang J, Duan G. 2015. Seroprevalence and risk factors of Toxoplasma gondii infection in buffaloes, sheep and goats in Yunnan province, southwestern China. Iranian Journal of Parasitology, 10, 648-651.

Cite this article as: Zhou Z, Wu Y, Chen Y, Wang Z, Hu S, Zhou R, Dong C, Lin H, Nie K. 2018. Molecular and serological prevalence of Toxoplasma gondii and Anaplasma spp. infection in goats from Chongqing Municipality, China. Parasite 25, 20 
O PARASTE

An international open-access, peer-reviewed, online journal publishing high quality papers on all aspects of human and animal parasitology

Reviews, articles and short notes may be submitted. Fields include, but are not limited to: general, medical and veterinary parasitology; morphology, including ultrastructure; parasite systematics, including entomology, acarology, helminthology and protistology, and molecular analyses; molecular biology and biochemistry; immunology of parasitic diseases; host-parasite relationships; ecology and life history of parasites; epidemiology; therapeutics; new diagnostic tools.

All papers in Parasite are published in English. Manuscripts should have a broad interest and must not have been published or submitted elsewhere. No limit is imposed on the length of manuscripts.

Parasite (open-access) continues Parasite (print and online editions, 1994-2012) and Annales de Parasitologie Humaine et Comparée (1923-1993) and is the official journal of the Société Française de Parasitologie. 